\title{
Invited review: Astringency in whey protein beverages
}

\author{
B. G. Carter, E. A. Foegeding, and M. A. Drake* ${ }^{\circ}$ \\ Department of Food, Bioprocessing and Nutrition Sciences, Southeast Dairy Foods Research Center, North Carolina State University, \\ Raleigh 27695
}

\section{ABSTRACT}

Astringency is the sensation of mouth drying and puckering, and it has also been described as a loss of lubrication in the mouth. Astringency is perceived as an increase in oral friction or roughness. Astringency caused by tannins and other polyphenols has been well documented and studied. Whey proteins are popular for their functional and nutritional quality, but they exhibit astringency, particularly under acidic conditions popular in high acid ( $\mathrm{pH} 3.4$ ) whey protein beverages. Acids cause astringency, but acidic protein beverages have higher astringency than acid alone. Whey proteins are able to interact with salivary proteins, which removes the lubricating saliva layer of the mouth. Whey proteins can also interact directly with epithelial tissue. These various mechanisms of astringency limit whey protein ingredient applications because astringency is undesirable to consumers. A better understanding of the causes of whey protein astringency will improve our ability to produce products that have high consumer liking and deliver excellent nutrition.

Key words: whey protein beverage, astringency, sensory analysis, consumer liking, nutrition

\section{INTRODUCTION}

Astringency, the sensation of mouth drying and puckering, is formally defined as "complex sensations due to shrinking, drawing or puckering of the epithelium as a result of exposure to substances such as alums or tannins" (ASTM International, 2004). This response to astringency has been thought to be an early warning sign of foods that could be potentially harmful.

Astringency may be more complicated than the mechanisms that underlie $\mathrm{G}$ protein-coupled taste receptors for the sensations of sweet, bitter, and umami tastes (Damak et al., 2003; Zhao et al., 2003; Zhang et al., 2003; Bradbury, 2004) and the ion channels that

Received February 1, 2020.

Accepted March 5, 2020.

*Corresponding author: maryanne_drake@ncsu.edu contribute to salty and sour tastes (Chandrashekar et al., 2006; DeSimone and Lyall, 2006). Astringency is tremendously important to the sensory perception of common foods including red wine, teas, chocolate, fruits, nuts, and protein products (Lesschaeve and Noble, 2005). Some of the compounds that cause astringency in foods are alum (Peleg et al., 1998), acids (Lawless et al., 1996), and polyphenols (Lesschaeve and Noble, 2005), as well as dehydrating agents (ethanol and acetone) and some organic acids (Bajec and Pickering, 2008). The sensation of astringency may not only be a consequence of the somatosensory system, but a combination of taste and oral tactile mechanisms (Bajec and Pickering, 2008). For this reason, astringency has also been described as the loss of lubrication in the mouth, which is perceived as an increase in oral friction or roughness (Upadhyay et al., 2016).

Whey proteins are popular for their functional and nutritional quality. Once only typically consumed by athletes and bodybuilders, a larger segment of US consumers are now interested in having an increased amount of protein from the foods that they consume (Nielsen Company, 2015). With the consumer demand for more protein in products, the market has answered with protein beverages, bars, confections, cookies, and cereals. Dairy proteins, specifically whey proteins, remain the most desirable protein source to consumers (Harwood and Drake, 2019). Whey proteins aid in greater muscle protein synthesis than casein or soy protein following exercise or at rest in both young and older individuals (Tang et al., 2009; Pennings et al., 2011). Whey protein also aids in the prevention of sarcopenia, or muscle breakdown, which leads to people losing 3 to $8 \%$ of muscle mass per decade after the age of 30 (Paddon-Jones and Rasmussen, 2009; Liao et al., 2019). To achieve the latter benefit (maintenance of muscle mass), constant supplementation of 20 to 25 $\mathrm{g}$ of protein per meal must be maintained, especially from high-quality protein sources such as whey. This constant supplementation can be difficult to maintain, especially if the protein source is unpalatable.

Whey proteins are nonvolatile macromolecules with no inherent aroma; however, due to processing, whey protein ingredients have other molecules that are fla- 
vor active (Mahajan et al., 2004; Carunchia Whetstine et al., 2003, 2005; Wright et al., 2006, 2009; Drake, 2007). Each step in the production of whey protein ingredients potentially imparts flavors (Carter and Drake, 2018). Further, these flavors can carry over into finished products, which can limit their application and acceptability (Drake, 2006; Wright et al., 2009; Evans et al., 2010; Oltman et al., 2015). Astringency is a sensation documented in whey protein that can also carry through into the final application (Childs and Drake, 2010; Oltman et al., 2015; Zhang et al., 2020). Protein astringency may further limit protein ingredients used in protein-dense products because astringency can be an undesired oral sensation in some foods (Beecher et al., 2008).

Whey protein beverages can be formulated to have either neutral $\mathrm{pH}$ or low $\mathrm{pH}$. Neutral beverages $(\mathrm{pH}$ 6.8-7.0) are cloudy and are typically formulated with sweet flavors such as vanilla, chocolate, or coffee. Acidic whey protein beverages $(\mathrm{pH}<3.5)$ are clear and tend to be formulated with fruity flavors that are congruent with low pH (Ahmadi et al., 2018). Acidic whey protein beverages are an appealing protein delivery system because they can be shelf stable with relatively mild heat treatment (compared with neutral beverages) and hotfilled. High intensities of astringency have been noted in high-acid whey protein beverages (Beecher et al., 2008; Childs and Drake, 2010), but perceivable astringency is still common in neutral beverages (Withers et al., 2014). Such astringency was recently documented as a driver of consumer dislike of neutral $\mathrm{pH}$ ready-tomix whey protein beverages (Zhang et al., 2020). The ability to create protein beverages with lower or no astringency would greatly improve consumer acceptance of these products. The ability to reduce astringency in acidic beverages would also enable the dairy industry to make a high-quality nutritional product with simpler processing and shelf stability.

Little published work has directly addressed the role of dairy protein astringency on consumer acceptance. Childs and Drake (2010) investigated consumer perception of astringency in clear acidic whey protein beverages. Consumers were unfamiliar with the terminology of astringency but understood the concept. Consumers were familiar with astringency in certain foods such as wine, juice, and tea.

The ability to produce protein products with low astringency is extremely important for the success of whey protein applications. The exact mechanism of astringency produced by dairy proteins (casein, whey) is still unclear. This literature review will summarize the current status of the literature and discuss the proposed mechanisms and factors that control and contribute to astringency in whey protein beverages.

\section{METHODS FOR MEASURING ASTRINGENCY}

First, to understand the causes of astringency, it is important to understand the different techniques to quantify it. Astringency is a sensory perception. As such, most research focused on astringency has used some form of descriptive analysis as a way to quantify it (Sano et al., 2005; Beecher et al., 2008; Lee and Vickers, 2008; Kelly et al., 2010; Vardhanabhuti et al., 2010; Ye et al., 2011, 2012; Bull et al., 2017). This method requires training a small group of individuals on reference solutions to enable them to scale and differentiate samples (Drake, 2007). Most studies have used a descriptive analysis panel to document astringency intensities, although temporality has also been characterized (Kelly et al., 2010; Beecher et al., 2008). Not all descriptive analysis methods are the same, and most scales are not related or they differ in reference types, which hinders making comparisons across studies. However, because astringency is a sensory sensation, humans and objective sensory methods remain the optimum way to measure the perception of astringency. Consumers are aware of the concept of astringency (Childs and Drake, 2010), but this awareness is not sufficient for quantifying astringency. Consumers do not have the training to identify and objectively quantify astringency or to differentiate astringency from other basic tastes such as sour or bitter.

Other indirect methods of measuring astringency, such as using a taste sensor that measures a change in membrane potential caused by sample adsorption on a probe, have been used (Sano et al., 2005). Some studies have used the rate of saliva flow, measured by collecting saliva after exposure to a stimulus for $2 \mathrm{~min}$, as an indirect indicator of astringency (Kelly et al., 2010). Saliva flow can be used as an indicator of astringency because more saliva is produced in an attempt to clear the astringent compounds and return the mouth to normal conditions. Astringent compounds, such as those found in tea, have been demonstrated to induce different perceptions of astringency that correlate with different saliva flow rates (Dawes et al., 2000).

Because astringency has been associated with interactions between proteins found in saliva and on oral surfaces, in vitro analysis of interactions is used alone or alongside sensory analysis to determine astringency. Change in turbidity has been used as an indicator of aggregation, either for whey protein aggregates alone or for whey protein-saliva protein aggregates (Beecher et al., 2008; Kelly et al., 2010; Ye et al., 2011). Individual proteins can be determined by electrophoretic analysis, and this approach has been used to characterize composition of protein aggregates formed in the mouth (Vardhanabhuti et al., 2010; Ye et al., 2011). Beside 
composition, particle size distribution of the aggregates may be important (Ye et al., 2011).

Aggregates can be formed by various forces including electrostatic interactions. A common way to analyze proteins with regard to their propensity for electrostatic interactions is to measure the zeta potential. This measurement provides an average protein charge (positive or negative) at a given $\mathrm{pH}$ and specific ionic conditions. Therefore, it can be useful to understand the potential interaction between charged molecules. Zeta potential was used to understand electrostatic interactions between saliva and whey proteins, and it showed that astringency was correlated with a decrease in zeta potential in the range tested $(\mathrm{pH} 3-5)$, which suggests greater interactions between whey protein and saliva when the charge states encourage interaction (Ye et al., 2011, 2012).

Tribology is the science of interacting surfaces in relative motion and therefore offers a framework for measuring the lubrication element of astringency ( $\mathrm{Li}$ et al., 2018b). Tribology has been used to understand the frictional component of astringency (Rossetti et al., 2008, 2009; Upadhyay et al., 2016), but reduction of friction alone does not appear to explain astringency. Rossetti et al. (2009) used tribology (preadsorbing saliva on elastic hydrophobic substrate) in conjunction with descriptive analysis to compare astringent polyphenols. Although the sensory scores of epigallocatechin gallate and epicatechin were similar for astringent intensity, the effect of each polyphenol on the model saliva surface differed. Epicatechin disrupted the saliva layer less than epigallocatechin gallate, but this finding did not track with sensory data. These results suggest that astringency differs from compound to compound and multiple mechanisms are occurring simultaneously.

Tribology has provided important insights on wine, which have been reviewed by Laguna and Sarkar (2017). A notable topic from this review is the effect of astringents on lubrication in the boundary regimen. Correlations have been made between the friction coefficient and astringency of saliva-wine complexes, which point to the ability of astringents to deplete salivary protein lubrication (Brossard et al., 2016). Another study showed that tannic acid found in wine was able to disrupt the boundary lubrication of adsorbed mucins (Ma et al., 2016). This disruption most likely leads to a change in hydration and conformational changes in bound mucins that lead to a rise in friction coefficients. Whey protein and wine may not interact with oral tissues in the same manner, but the evidence suggests that disruption of factors associated with boundary regimen lubrication leads to a sensation of astringency, which appears to occur with both astringents.
Tribology has also been used to evaluate the role of heat treatment on astringency of milk. Friction coefficients quantify the frictional force between 2 moving surfaces that are lubricated with the material under investigation (e.g., milk or whey protein beverage). A higher value friction coefficient means greater friction between the surfaces. In ultrapasteurized milk, friction coefficients and astringency were positively correlated (Li et al., 2018a,b). Because astringency is often described as roughness in the mouth, a complete understanding of how protein solutions alter friction may give us more information on how the mechanical processing of food in the mouth may influence astringency perception. Most of the interaction of food and lubricating oral surfaces is governed by the principles of bulk rheology, the surface properties of the constituents, and the confinement or exclusion of microstructural components in the contact zone (de Vicente et al., 2006).

Although the methods just discussed are essential to understanding the molecular mechanism for astringency, a well-trained descriptive analysis panel with a specific protocol is the most direct tool for quantifying astringency. After exposure to an astringent food, it takes several minutes for the mouth to return to a normal mouthfeel (Hans et al., 2016). In the sensory sciences, the lingering sensation is referred to as the carry-over effect. It takes longer for the mouth to clear sensations such as astringency, which requires either a rinse solution or proper rest time between samples (Torrico et al., 2018). The human mouth produces more saliva in response to astringency. As new saliva is secreted, it helps to clear the astringent compounds from the mouth and return it to a normal $\mathrm{pH}$ and level of hydration. The time needed for this process is why astringency lingers and does not fully clear from the mouth for several minutes. Important in the evaluation of astringency is a proper protocol to prevent carryover of astringency from sample to sample. During sensory evaluations of astringency, a rinse solution is often used to help the mouth return to normal between samples. Many rinses are good to minimize astringency carryover with a variety of foods. Moreover, the need for the rinsing supports the idea that astringency is associated with some change in oral surfaces that needs to be reversed. Vickers et al. (2008) evaluated palate cleansers for evaluating sourness and reported that crackers worked better than water. The best palate cleansers reported for astringency in red wine were crackers, carboxymethyl cellulose $(0.55 \%)$, and pectin $(0.1 \%$; Brannan et al., 2001; Colonna et al., 2004; Ross et al., 2007; Lee and Vickers, 2010). A rest time of 2 to 5 min between samples is also recommended. Ultimately, the standard for the quantification of astringency is a highly trained sensory panel. General sensory prac- 
tices for trained panels have been previously reviewed (Drake, 2007).

\section{MECHANISM FOR ASTRINGENCY}

Based on better studied substances such as tea and wine, the normal model for astringency indicates that it is cause by polyphenols. This mechanism was described by Bate-Smith (1973) as an association between prolinerich salivary proteins and polyphenols that produces insoluble complexes. The complexes can then precipitate or aggregate, causing loss of lubrication in the mouth and deformation of the mucosal pellicle (Ployon et al., 2018). The mucosal pellicle is a thin layer of salivary proteins attached to the oral epithelium by covalent and noncovalent bonds (Gibbins et al., 2014). Certain salivary proteins, including proline-rich protein (Hay and Oppenheim, 1974), mucin (Tabak et al., 1982), a-amylase (Aguirre et al., 1989), and statherin (Douglas et al., 1991), have been shown to provide lubrication in the mouth. Complexation or aggregation of these proteins with astringents could therefore reduce the lu- bricity experienced in the mouth and lead to increased friction and roughness in the mouth. This scenario has led to the theory proposed by Horne et al. (2002) that astringency is at least initially caused by delubrication via removal of the slippery coating on oral surfaces, exposing mechanoreceptors resulting in roughening, tightening, and drying sensations.

Most recently, research has concluded that many factors and possibilities contribute to astringency. Notably, the proposed mechanisms of polyphenol-protein aggregates that disrupt the salivary film and different interactions with mechanoreceptors on the tongue and oral surfaces, aided by the loss of lubricity, make astringency difficult to define and control (Gibbins and Carpenter, 2013). An example of the mechanisms of astringency caused by polyphenols is summarized in Figure 1.

Recent reviews describe the mechanism of astringency caused by tannins and polyphenols (Bajec and Pickering, 2008; Gibbins and Carpenter, 2013). The current review focuses on the astringent sensation caused by whey proteins.
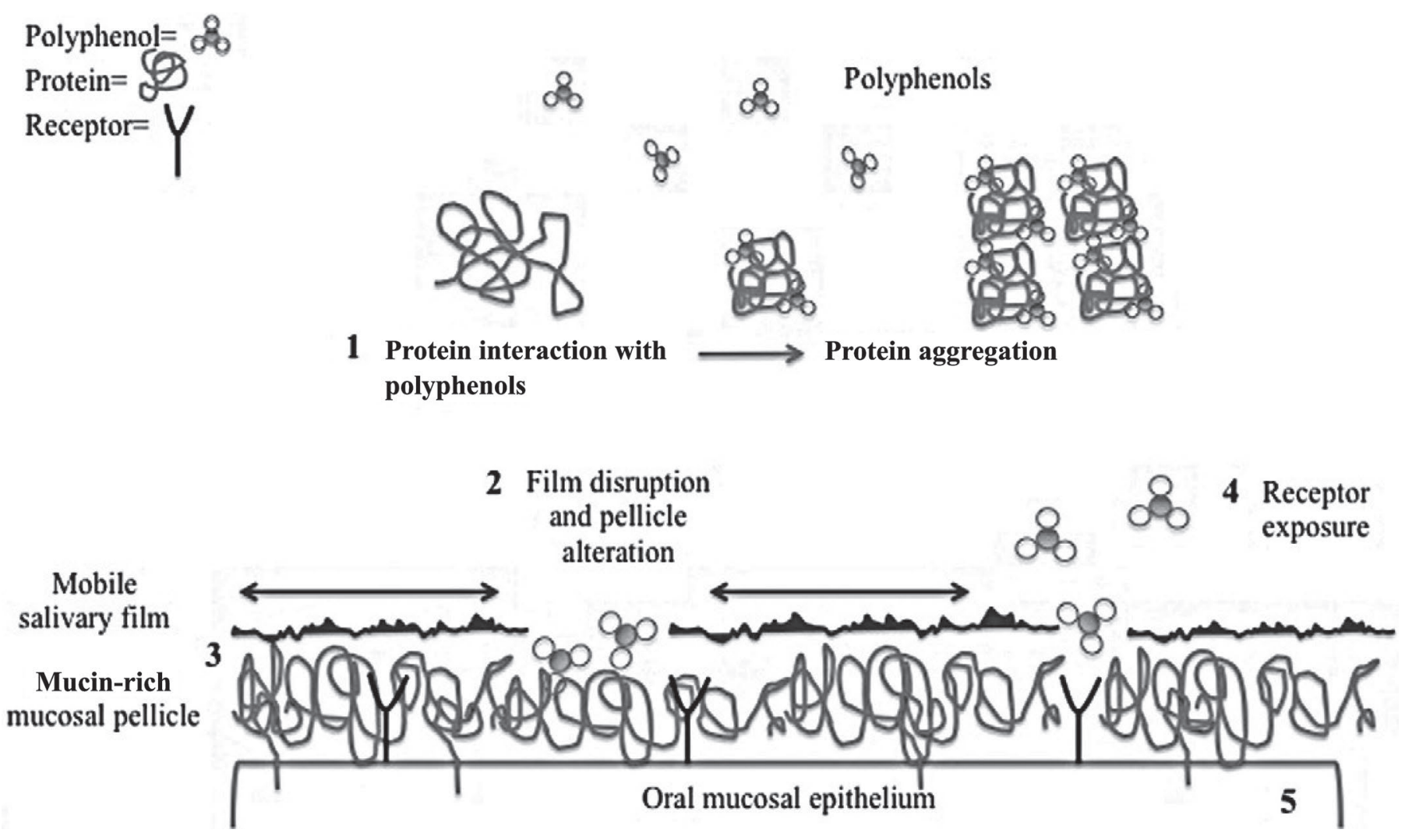

Figure 1. Possible mechanisms of astringency occurring simultaneously in the oral cavity. Adapted from Gibbins and Carpenter (2013), with permission. (1) Aggregation of salivary proteins creating grittiness; (2) salivary film disruption; (3) reduced salivary lubrication; (4) exposure of receptors; and (5) nociceptors/mechanoreceptors or nerve innervation. 


\section{MECHANISMS FOR WHEY PROTEIN ASTRINGENCY}

Some of the same mechanisms by which polyphenols drive astringency may also underlie the astringency associated with whey proteins. Several proposed mechanisms provide some explanation of the astringency caused by or contributed by the addition of whey protein. Some common proposed mechanisms include astringency of whey protein beverages being solely due to the acidity of the solution, whey protein-saliva interactions delubricating oral surfaces, whey protein aggregates interacting directly with oral receptors, and whey protein-saliva aggregates causing an increase in oral friction.

\section{Astringency Due to Acid Alone}

Some researchers believe that astringency is caused by the acidity of the solution and is not influenced by the concentration or presence of protein. The acidity alone causes the loss of lubrication in the mouth that leads to the mouth-drying sensation of astringency. Lee and Vickers (2008) tested this hypothesis directly by preparing 1 or $6 \%$ (wt/wt) whey protein isolate solutions at $\mathrm{pH}$ 3.4. Control beverages with the same volume of phosphoric acid required to attain $\mathrm{pH} 3.4$ in the whey protein beverages and a water control adjusted to pH 3.4 were also prepared. A trained panel quantified astringency intensities. Acid control samples had higher astringency than the acidic whey protein solutions. The researchers concluded that astringency was caused by high acidity rather than by the whey proteins. Acids have been shown to cause astringency (Lawless et al., 1996) and clearly have a major impact on overall astringency, but the conclusion that acid is the sole cause of astringency omits research demonstrating that proteins contribute directly to astringency. The whey protein solutions in the previously mentioned study differed in titratable acidity, but it is $\mathrm{pH}$ not titratable acidity that dictates the unique functionality, solubility, and flavor of whey protein (Pelegrine and Gasparetto, 2005). Titratable acidity is perhaps not the best measure of a solution's predicted astringency but is instead more related to the solution's buffering capacity. The study presented by Lee and Vickers (2008) had some limitations. Panelists were not highly trained, having only attended two 1-h sessions to distinguish between acidity and astringency; other studies included $>30 \mathrm{~h}$ of training over several months for panelists to learn to differentiate and scale these sensations (Beecher et al., 2008). The mere fact that they were not highly trained does not discredit their findings; however, extensive training is generally required to generate consistent data between sessions, particularly for a complex sensation such as astringency (Lawless and Heymann, 2010).

In an experiment of different organic acids (lactic, malic, tartaric, citric) and the relative astringency at different acid concentrations, lowering the $\mathrm{pH}$ of acid solutions, while holding the acid concentrations the same, resulted in increases in astringency. Therefore, astringency is correlated with $\mathrm{pH}$ not titratable acidity (Sowalsky and Noble, 1998). Acids themselves cause astringency and the astringency lingers (Sowalsky and Noble, 1998), but sourness as a sensation does not linger after expectoration (Rubico and McDaniel, 1992; Hartwig and McDaniel, 1995). These facts suggest that acids induce some changes in mucosal proteins that cause the lingering astringency, and it is not merely due to the presence of acid.

Sano et al. (2005) reported that $5 \mathrm{~m} M$ sodium phosphate buffer at $\mathrm{pH} 3.5$ did not elicit astringency but once $5 \%$ (wt/wt) whey protein was added, astringency increased. Whey protein at that $\mathrm{pH}$ caused the astringent sensation. Other research (Beecher et al., 2008) showed that astringency of whey protein solutions $(6 \%$ wt/vol) decreased between the $\mathrm{pH}$ of 3.4 and 2.6 although a concurrent increase in sour taste occurred. This phenomenon seems to contradict most of the previous research showing that astringency increases as $\mathrm{pH}$ becomes lower. The shift in astringency that occurs at $\mathrm{pH} 3.4$ is possibly explained by changes in associative interactions within the complex mixture of whey proteins and those found in the oral cavity (saliva proteins and those associated with oral mucosa). These results indicate that astringency is not solely dependent on $\mathrm{pH}$ or titratable acidity. Certain whey proteins, including lactoferrin, are positively charged at neutral $\mathrm{pH}$ and cause astringency, which suggests that protein along with $\mathrm{pH}$ contributes to astringency (Vardhanabhuti et al., 2010).

\section{Whey Protein-Saliva Interaction Delubricating Oral Surfaces}

Oral lubrication is extremely important to normal mouthfeel conditions (Sarkar et al., 2019). Loss of lubrication plays a role in many of the proposed mechanisms of astringency and is part of the reason astringency is so difficult to define. Salivary proteins provide a slippery coating to oral surfaces that aids in the breakdown of food and the formation of a bolus that facilitates swallowing. Saliva flow rates for a normal individual are approximately 0.3 to $0.4 \mathrm{~mL} / \mathrm{min}$ without a stimulus (Iorgulescu, 2009), and the slippery surface in the mouth is constantly being replenished as a person swallows, eats, and drink. During food consumption, saliva 
flow rates increase due to the anticipation of breaking down food. Salivary flow rates may also increase after swallowing to help the mouth return to a normal state and to protect the oral cavity (Iorgulescu, 2009; Hans et al., 2016).

Acidic beverages produce some of the fastest salivary flow rates because continued exposure to acid could harm the teeth (Hans et al., 2016). Salivary flow rates are therefore increased with acidic foods to return the mouth to a normal $\mathrm{pH}$. The salivary film is the first barrier of defense between the oral epithelium and food. Its disruption would allow various interactions to occur in the oral cavity and potentially expose oral receptors that are normally protected by the salivary film. Astringent compounds disrupt the normal mouthfeel, which has been described as a tactile feeling with no abrasion between rubbing surfaces aided by hydrated surfaces maintained by thin film of saliva (Gibbins and Carpenter, 2013). Disruption of the salivary film layer, as explained in the previous definition, would lead to abrasion and rubbing of unhydrated surfaces in the mouth. Delubrication by removal of this slippery thin layer of saliva on oral surfaces could expose epithelial tissues and receptors, causing the roughening, tightening, and drying sensations often associated with astringency.

Saliva is rich in mucins, and mucins have therefore been the most studied for understanding interactions of various substances with saliva. Mucins are large highly glycosylated glycoproteins that play a major role in maintaining the viscoelastic properties of saliva and the protective oral mucosal coating (Slomiany et al., 1996). Mucins typically have negatively charged groups from sialic acid residues and thus have a low isoelectric point, estimated to be between 2 and 3 (Çelebioğlu et al., 2020). Whey protein complexation with saliva (possibly mucin) could involve binding to the salivary film and allowing whey protein to interact directly with the mucosal pellicle as well as newly exposed receptors.

Alternatively, astringency could be due to interactions between the positively charged whey proteins $(\mathrm{pH}<\mathrm{pI})$ and negatively charged proteins dispersed in saliva (Beecher et al., 2008). If salivary proteins have isoelectric points below those of whey proteins, the resulting $\mathrm{pH}$ range will cause a net electrostatic attraction leading to aggregation between whey and saliva proteins. Therefore, rather than precipitation of whey proteins themselves due to $\mathrm{pH}$ changes, astringency of whey proteins could be related to interactions with salivary proteins carrying opposite charges, such as proline-rich proteins or mucins. This possibility fits one aspect of the polyphenol astringency shown in Figure 1. Hsein et al. (2015) made solutions of whey protein $(0.25-4.0 \% \mathrm{wt} / \mathrm{vol})$ and mucins $(1 \%$, sourced from porcine stomach) to investigate the mucoadhesive properties of whey protein. Mucoadhesion is the adhesion between 2 materials, one of which is a mucosal surface (Shaikh et al., 2011). Whey protein exhibited mucoadhesive properties and interacted with mucin across a wide $\mathrm{pH}$ range of 1.2 to 4.5 in a model solution, suggesting that it was binding with unbound salivary proteins or salivary proteins attached to oral surfaces. An important unanswered question is whether bound or unbound mucins interact with whey protein first. If whey proteins are in large supply, both groups of mucins would interact with whey proteins until the mouth produces enough saliva to clear the mouth. If astringents interact directly with salivary proteins found on oral surfaces, then their detection may not require oral movement because the response would be related to binding and not friction. However, this possibility does not rule out roles for surface binding and friction in astringency.

Different research groups have investigated potential factors that could overcome the loss of lubrication, such as changes in viscosity and hydrocolloid complexation and the addition of fat. Beecher et al. (2008) investigated the effect of viscosity of whey protein beverages on the sensory perception of astringency. Beverages contained $6 \%$ (wt/vol) whey protein, phosphoric acid to decrease $\mathrm{pH}$ to 3.4 , and sucralose for sweetness. Maltodextrin at $0,10,15$, and $20 \%$ (wt/vol) and methyl cellulose at $0.27 \%$ (wt/vol) were used to manipulate viscosities $\left(1.6-7.7 \mathrm{mPa} \cdot \mathrm{s}\right.$, shear rate 10 and $\left.100 \mathrm{~s}^{-1}\right)$. Astringency among the beverages did not differ with increases in instrumental viscosity. Withers et al. (2014) made a range of protein beverages $(7.0-8.7 \%$ wt/wt, $\mathrm{pH} 7$ ) with different casein (milk protein concentrate, sodium caseinate, calcium caseinate) and whey protein (whey protein concentrate, WPC75) ratios and viscosities (15.1-42.8 $\mathrm{mPa} \cdot \mathrm{s}$, shear rate $44 \mathrm{~s}^{-1}$ ), and subjected the samples to pasteurization $\left(60^{\circ} \mathrm{C}, 15 \mathrm{~min}\right)$. The viscosity of different treatments had minimal to no effect on the perception of astringency. These results suggest that, at least within the range tested, viscosity does not affect the perception of astringency in dairy protein beverages at high or low $\mathrm{pH}$. However, these studies only focused on a fluid range of viscosities. Most whey proteins are consumed as beverages, but viscosity may possibly affect astringency of thicker fluids, or even semi-solid foods such as bars, which are another common protein food. Viscosity has been shown to manipulate astringency with polyphenols; therefore, a comparison of studies on how viscosity mediates the effect of various astringents is important. Various viscosities were investigated to determine their effect on the astringency of grapeseed tannin (1.9-45.3 $\mathrm{mPa} \cdot \mathrm{s}$; Smith et al., 1996) and aluminum sulfate and citric acid (1-29 mPa.s, 
Smith and Noble, 1998). The greatest reductions in astringency occurred with increases from 1 to $5 \mathrm{mPa} \cdot \mathrm{s}$ and from 5 to $10 \mathrm{mPa} \cdot \mathrm{s}$. After $10 \mathrm{mPa} \cdot \mathrm{s}$, viscosity only had a minor influence on astringency (Smith and Noble, 1998). Therefore, to reduce astringency caused by polyphenols, increasing the viscosity of the solution to $10 \mathrm{mPa} \cdot \mathrm{s}$ provides the greatest impact. Increased viscosity appears to reduce astringency from polyphenols and acids, although it has little effect on whey protein solutions.

Certain hydrocolloids, including high methoxy pectin, have been used to form complexes with whey protein that are more heat soluble (Wagoner et al., 2016). Previous work has shown that the addition of pectin to astringent fruit juices reduces the perceived astringency because the pectin forms complexes with the soluble tannins, which prevents the interaction of salivary protein and tannins (Taira et al., 1997; Soares et al., 2012). No work has been done to quantify the astringency of whey protein-pectin complexes, but if they function similarly to tannin-pectin complexes in fruit juices, it may be possible to reduce the astringency of whey proteins by complexing them with pectin. However, whey protein-pectin complexes create turbid beverages, which may limit their acceptability in final applications (Wagoner and Foegeding, 2017).

The presence of fat decreased astringency in ultrapasteurized milk (Lee et al., 2017; Li et al., 2018b). Fat may act as a lubricant that reduces perceived roughness and friction in the mouth, and it is also possible that fat competes with protein via the mucoadhesion mechanism and limits perceived astringency. However, the addition of fat to higher protein beverages (7-11.8\%) appeared to have little effect on astringency and may have even increased it (Withers et al., 2014). In contrast, des Gachons et al. (2012) proposed that oral fatty sensation and astringency are opposite sides of the sensory perspective. Fat provides lubrication and is perceived as slippery, while astringent compounds create a dry and rough mouthfeel. The addition of fat may help reduce astringency in neutral whey protein beverages, but it would increase their turbidity. Acidic whey protein beverages are characteristically clear, and the addition of lipid would make them turbid, most likely lowering their acceptance. More work is needed to confirm how adding fat in acidic conditions would influence perceived astringency.

\section{Whey Protein Aggregates that Interact Directly with Oral Surfaces}

Different whey proteins contribute differently to astringency. The majority of whey proteins have similar charge states at varying $\mathrm{pH}$ values. $\beta$-Lactoglobulin has a reported isoelectric point of pH 5.2 (Cannan et al., 1942), and $\alpha$-LA has a reported isoelectric point of $\mathrm{pH} 4.8$ (Zittle, 1956). Lactoferrin differs from the other whey proteins and has an isoelectric point of 8.8, meaning that it has a net positive charge in the normal neutral protein beverage range $(\mathrm{pH}$ 6.6-7.0). Lactoferrin had a much lower astringency threshold compared with $\beta$-LG at pH 3.5, 0.5 versus $3.0 \%$ (Ye et al., 2012). Lactoferrin had significant astringency at a $0.1 \%$ (wt/ vol) protein concentration at both $\mathrm{pH} 3.5$ and 7.0. Ye et al. (2012) demonstrated that the perception of astringency may involve binding to oral epithelial cells, based on an ELISA test with HSC-2 or NO-1-N-1 cells. The authors then conducted a series of dilutions with both $\beta-\mathrm{LG}$ and lactoferrin to determine the concentrations of these proteins that remained bound to the cells. These results do not preclude the possibility of multiple mechanisms, including interactions between whey proteins and salivary proteins. Lactoferrin had much stronger binding of oral epithelial cells than $\beta$-LG, which may explain the high level of astringency associated with lactoferrin. Astringency of lactoferrin was displayed at $\mathrm{pH}<7.0$ without the formation of precipitated saliva (Vardhanabhuti et al., 2010). Because lactoferrin carries a net positive charge at $\mathrm{pH}$ values below 8.8 , it can potentially interact with negatively charged proteins found in the saliva or on oral surfaces under neutral and acidic beverage conditions.

The composition of whey protein changes with different cheese-making procedures or the method of purifying protein streams, and such differences in composition may contribute to the perception of astringency. For example, the protein profile of whey protein isolate made with a microfiltration-based process differs from the profile of isolate prepared by ion exchange. Glycomacropeptide (GMP) results from rennet cleavage of $\kappa$-casein during cheese manufacture. Ultrafiltration retains this peptide, which composes a large portion of the whey protein powder, approximately 20\% (Farías et al., 2010). During ion exchange, however, the GMP is not retained in the final powder. No research has evaluated the direct impact of GMP on astringency, but GMP provides an example of how whey protein powders can differ in protein composition. Astringency of the whey proteins lactoferrin and $\beta-\mathrm{LG}$ have been documented, presumably due to their unique PI and prevalence, respectively. To our knowledge, the contributions of other whey proteins to astringency have not been specifically addressed.

Neither whey proteins nor salivary proteins precipitate on their own without changes in heat or $\mathrm{pH}$. Mixing whey proteins with saliva produces a precipitated phase that contains salivary and whey proteins (Vardhanabhuti et al., 2010). Measuring the turbidity 
of saliva and $\beta$-LG mixtures at different $\mathrm{pH}$ values demonstrated that the maximum turbidity of the mixture occurred between $\mathrm{pH} 4.6$ and 5.2. Beecher et al. (2008) also reported that high levels of astringency in whey protein beverages were correlated with increased turbidity of saliva and protein mixtures.

Whey protein aggregates may contribute directly to astringency. Larger size whey protein aggregates change the texture of the salivary film in the mouth, and as surfaces rub, the sensation of astringency may increase. Turbidity in whey protein beverages increases as the size of the whey protein aggregates increases from 0.1 to $3 \mu \mathrm{m}$ (LaClair and Etzel, 2009). If the size of particles undergo further change due to oral conditions, a change in the fluid saliva composition could occur and create greater oral friction. This development would increase the perception of astringency, especially with the delubrication of oral surfaces considered in the previous section. These whey protein aggregates may lead to tactile changes without any contribution by salivary proteins. Interactions between whey protein and salivary proteins will be discussed later. Sano et al. (2005) reported that most whey proteins, including $\beta-\mathrm{LG}$, the most abundant whey protein, precipitate at around $\mathrm{pH} 5$. When an acidic whey protein solution ( $\mathrm{pH} 3.5$ ) is mixed with saliva $(\mathrm{pH} \sim 7.0)$, the average $\mathrm{pH}$ of the mixture would be $\sim 5$, causing precipitation of protein (Sano et al., 2005). The precipitated protein particles would create astringency similar to the way that polyphenols and salivary proteins create complex precipitants that reduce lubrication and create roughness.

Whey protein aggregation can also be caused due to excessive heating. The most abundant whey protein, $\beta-\mathrm{LG}$, denatures and aggregates at around $70^{\circ} \mathrm{C}$ (Briggs and Hull, 1945). During the production of whey protein powders, the whey proteins pass through various heat processes that may cause denaturation and aggregation. Bull et al. (2017) found that heating whey protein concentrate solutions $(10 \% \mathrm{wt} / \mathrm{vol}$, $\mathrm{pH}$ 6.5-6.7) for longer periods $\left(70^{\circ} \mathrm{C}\right.$ for 5,10 , or 20 min) led to increased astringency. The researchers also documented that an increase in astringency occurred with repeated consumption, suggesting mucoadhesion of whey proteins. This phenomenon of increased denaturation or aggregation increasing mucoadhesive strength of whey proteins has been noted before (Hsein et al., 2015). This result is also consistent with the results of Lee et al. (2017) and Li et al. (2018b), who found that ultrapasteurized milk had higher astringency scores than HTST pasteurized milk. Previous research has shown that whey proteins are primarily responsible for astringency in milk and milk beverages (Withers et al., 2014). Heat treatment has a major effect on whey protein, which translates into changes in the perception of astringency.

Ye et al. (2011) determined that heated $\left(90^{\circ} \mathrm{C}\right.$ for 10 min) and unheated $\beta$-LG solutions (2\%) mixed with saliva had higher particle size and turbidity at $\mathrm{pH}$ 3.4 than $\beta$-LG solutions alone. This observation was likely due to $\beta$-LG and salivary proteins having opposite charges at this $\mathrm{pH}$, which may lead to complexation through electrostatic interactions. Protein and saliva mixtures that were heated had higher turbidity and larger particle sizes at $\mathrm{pH}>5.0$ than unheated samples. The heat treatment most likely denatured and aggregated some of the whey protein, which increased particle size. Increases in astringency and particle size were consistent and positively correlated over the $\mathrm{pH}$ range of 3.0 to 3.6 , suggesting that denaturation or aggregation adds to the astringency associated with native proteins. Whey proteins and salivary proteins interact via electrostatic interactions at $\mathrm{pH} 3.4$, whereas only salivary proteins undergo aggregation at $\mathrm{pH} 2.0$. It appears that forming protein aggregates alone does not necessarily correlate to astringency because high particle size and turbidity at $\mathrm{pH} 5.0$ did not cause the perception of astringency (Ye et al., 2011) even though charge interactions between whey protein and saliva were demonstrated.

The astringency of whey protein beverages increased as protein load increased under high-acid ( $\mathrm{pH} 3.5$; Sano et al., 2005) and low-acid (pH 6.8; Beecher et al., 2008) processing conditions. Kelly et al. (2010) reported that astringency of whey protein beverages increased with increasing protein concentration from 0.25 to $4 \%$ (wt/ wt) at $\mathrm{pH} 3.5$. Higher protein levels had a lower dose response, with little increase of astringency from 4 to $13 \%$ (wt/wt) even though the acid concentration increased with increased buffering capacity. Although no increase of astringency occurred beyond $4 \%$ (wt/ wt) protein experimentally, it is reasonable to assume that depending on the mechanism, more stimuli would create a more astringent sensation. Childs and Drake (2010) also showed an increase in astringency with an increasing concentration of protein up to $6 \%$ (wt/wt) in a model whey protein beverage at $\mathrm{pH} 3.4$. Oltman et al. (2015) reported that increasing the protein load from 4 to $8 \%$ (wt/wt) also increased the perceived sensory astringency in acidic whey protein beverages ( $\mathrm{pH} 3.2)$. An experimental maximum of protein astringency at $\mathrm{pH} 3.5$ has not been determined.

\section{Whey Protein Saliva Aggregates that Overcome Lubrication in the Mouth, Increasing Oral Friction}

Astringency values of whey protein solutions rated by a descriptive analysis panel increased with increas- 
ing turbidity (an indicator of aggregation) of the solutions (Beecher et al., 2008). This result suggests that not only are saliva proteins able to interact with whey proteins, but the end result creates larger-sized particles that scatter more light and appear to increase the perception of astringency even though the exact mechanism is not known. A more direct experiment needs to be conducted with whey protein aggregates created over a range of sizes to determine the direct impact on perceived astringency.

Ye et al. (2011) combined mixtures of saliva and $\beta$-LG $(2 \%)$ at various $\mathrm{pH}$ values from 2 to 7 . Whey and saliva mixtures were turbid between $\mathrm{pH} 3$ and 4 . The particle size of human saliva was 100 to $500 \mathrm{~nm}$ and increased gradually as $\mathrm{pH}$ decreased from $\mathrm{pH} 7$ to 3. Below $\mathrm{pH} 3$, saliva particles rapidly increased in size to over $2,000 \mathrm{~nm}$. The particle size of both $\beta-\mathrm{LG}$ and saliva separately was similar at $\mathrm{pH} 7$ to 4.7; however, the particle size of their mixture was larger in the range of pH 3.0 to 4.7 (Ye et al., 2011). Astringency results collected by descriptive analysis also showed that peak astringency occurred at $\mathrm{pH} 3.4$, which was also associated with the most turbid saliva-protein mixture and the largest particle size (3.5 um). At pH 2.5 perceived astringency was lower, which could be explained by the salivary protein (mucin) having a minimal charge at that $\mathrm{pH}$.

Saliva flow rates have also been studied as a possible method to assess astringency increase and plateau at higher $\beta$-LG concentrations (10\% wt/vol). Saliva flow rates for individuals increased as protein concentrations increased from 0.5 to $10 \%$ (wt/wt) (Kelly et al., 2010). This finding is important because if saliva interacts with whey protein and complexes form, a higher flow rate of saliva will produce more substrate for more astringent complexes (Kelly et al., 2010). Higher flow rates of saliva also replace astringent complexes bound to oral mucosal more quickly and can help return the mouth back to normal conditions.

Vardhanabhuti et al. (2011) investigated the effect of $\beta$-LG at $\mathrm{pH} 3.5$ and 7.0 on the lubricating property of saliva as related to astringency perception. Saliva was adsorbed onto surfaces of a rotating poly dimethyl siloxane ball and disc to form a film under conditions that mimic the rubbing contacts in the oral cavity (Bongaerts et al., 2007), and the lubricity of saliva films upon exposure to astringent compounds was measured. The addition of $\beta$-LG at $\mathrm{pH} 7.0$ slowly increased the friction of the saliva film between tribopair surfaces, but $\beta$-LG at $\mathrm{pH} 3.5$ rapidly increased the friction coefficients of saliva. This effect was similar to other astringent compounds, such as epigallocatechin gallate and alum. This result supports the hypothesis that astringency of $\beta-\mathrm{LG}$ arises from the loss of lubrication of saliva, which is in agreement with the well-accepted astringency model of polyphenols. Without the aid of the hydrating salivary film, large particles could be perceived by the tongue mechanoreceptors. With typical oral movement, exaggerated oral friction would occur due to a combination of the loss of lubrication and the increased number of perceived particles on the tongue and oral surfaces.

As previously mentioned, the mucosal pellicle is a region where salivary proteins are bound to the oral epithelium. Upon interaction with protein, new bonds can create a deformation of the mucosal pellicle, causing it to transition from a largely smooth surface to a rough surface. In a state of delubricated oral surfaces, this newly deformed oral epithelium can further exacerbate oral friction. The combination of multiple mechanisms further intensify the sensation of astringency.

All of the aforementioned mechanisms contribute to whey protein astringency and exacerbate each other's contributions. Targeted solutions to lowering the astringency of whey protein solutions should be aimed at limiting or preventing all mechanisms. The mechanisms for astringency also appear to be related to different ranges of $\mathrm{pH}$, so the most probable solutions may depend on the $\mathrm{pH}$.

\section{ACIDIC WHEY PROTEIN BEVERAGE SOLUTIONS}

As noted earlier, improving the palatability of acidic whey protein beverages has drawn great interest due to their lack of need of refrigeration and mild heating requirements. However, the greatest obstacle to their popularity is astringency (Oltman, et al., 2015). In light of the possible mechanisms of whey protein astringency, possible solutions exist to limit or minimize the perceived astringency in high-acid whey protein beverages.

The first consideration is acidification source. Because acids themselves can contribute astringency to beverages, it is important to choose an acidulant that has the smallest effect on astringency. Inorganic acids are more astringent than organic acids, and the best solution appears to be using a blend of acidulants that provide the correct $\mathrm{pH}$ adjustment, flavor profile, and sourness (Rubico and McDaniel, 1992). Acid selection is certainly important given the buffering of whey protein. Due to the buffering capacity of whey protein, increasing the protein load of a beverage requires adding more acid to hit the target $\mathrm{pH}$. Creating products with high levels of protein and using organic acids to adjust the $\mathrm{pH}$ may be problematic, however, because the products become more sour due to the amount of acid needed to reach the target $\mathrm{pH}$.

The second consideration is the prevention of whey and saliva proteins interactions. Given that the saliva 
is provided by the consumer, the whey protein beverage manufacturer has the innovation responsibility. As $\mathrm{pH}$ values decrease below the isoelectric points (pI) of whey proteins, they become positively charged and can interact with saliva proteins that have lower pIs. If whey proteins are electrostatically complexed with a charged polysaccharide, then in theory they will not interact with salivary protein. The strategy would also prevent whey proteins from binding or interacting with mechanoreceptors or the oral epithelial surface.

The third option is to add ingredients that would increase the oral lubricating properties in the beverage. With a beverage that provides lubrication in the mouth, oral friction should be minimized, which would limit the perceived astringency. The effect of viscosity on astringency perception has been studied, but most investigations focused on relatively fluid ranges (1.6-7.7 mPa.s, shear rate 10 and $100 \mathrm{~s}^{-1}$ ) (Beecher et al., 2008). Thicker beverages would theoretically slow the rate of diffusion of astringent compounds to oral surfaces. Acidic whey proteins do not typically use stabilizers because whey proteins are readily soluble at $\mathrm{pH}<4.6$. Some polysaccharides may be effective due to a combination of mechanisms, such as forming electrostatic-based complexes and altering viscosity, but any approach to decreasing astringency must not change the viscosity and clarity of the beverages such that consumer acceptance is decreased.

\section{CONCLUSIONS}

Astringency in whey protein beverages is a complex phenomenon. Astringency in foods has multiple mechanisms and several contributing factors. Consequently, defining the exact mechanism for astringency of products such as whey protein beverages remains a challenge. The precise molecular mechanism for astringency of whey protein remains unclear, although factors that alter the degree of astringency have been identified. As with polyphenol astringency, if the complexation of whey and salivary proteins can be reduced or prevented, astringency of whey protein should be reduced. Astringency is generated by both the whey protein itself and the acidity of the solution. More research is needed to understand how whey protein ingredient astringency can be minimized in order to increase the consumer liking of the product and allow manufacturers to deliver superior nutrition through whey products.

\section{ACKNOWLEDGMENTS}

Funding was provided in part by Dairy West (Meridian, ID) and the National Dairy Council (Rosemont,
IL). The authors have not stated any conflicts of interest.

\section{REFERENCES}

Aguirre, A., B. Mendoza, M. J. Levine, M. N. Hatton, and W. H. Douglas. 1989. In vitro characterization of human salivary lubrication. Arch. Oral Biol. 34:675-677. https://doi.org/10.1016/0003 -9969(89)90024-1.

Ahmadi, S. F., A. Nasirpour, S. A. H. Goli, and E. Riahi. 2018. Effect of heat treatment and solution preparation procedure on colloidal stability of whey protein sour cherry beverage. Int. J. Dairy Technol. 71:781-790. https://doi.org/10.1111/1471-0307.12498.

ASTM International. 2004. Standard definitions of terms relating to sensory evaluation of materials and products. Annual book of ASTM standards. ASTM International, West Conshohocken, PA.

Bajec, M. R., and G. J. Pickering. 2008. Astringency: Mechanisms and perception. Crit. Rev. Food Sci. Nutr. 48:858-875. https://doi.org/ 10.1080/10408390701724223.

Bate-Smith, E. C. 1973. Haemanalysis of tannins: The concept of relative astringency. Phyochemistry 12:907-912. https://doi.org/10 .1016/0031-9422(73)80701-0.

Beecher, J. W., M. A. Drake, P. J. Luck, and E. A. Foegeding. 2008. Factors regulating astringency of whey protein beverages. J. Dairy Sci. 91:2553-2560. https://doi.org/10.3168/jds.2008-1083.

Bongaerts, J., D. Rossetti, and J. Stokes. 2007. The lubricating properties of human whole saliva. Tribol. Lett. 27:277-287. https://doi .org/10.1007/s11249-007-9232-y.

Bradbury, J. 2004. Taste perception: Cracking the code. PLoS Biol. 2(3):E64.

Brannan, G. D., C. S. Setser, and K. E. Kemp. 2001. Effectiveness of rinses in alleviating bitterness and astringency residuals in model solutions. J. Sens. Stud. 16:261-275. https://doi.org/10.1111/j .1745-459X.2001.tb00300.x.

Briggs, D. R., and R. Hull. 1945. Studies on protein denaturation. I. Electrophoretic study kinetics at neutrality of heat denaturation of $\beta$-lactoglobulin. J. Am. Chem. Soc. 67:2007-2014. https://doi.org/ 10.1021/ja01227a044.

Brossard, N., H. Cai, F. Osorio, E. Bordeu, and J. Chen. 2016. Oral tribological study on the astringency sensation of red wine. J. Texture Stud. 47:392-402. https://doi.org/10.1111/jtxs.12184.

Bull, S. P., Y. Hong, V. V. Khutoryanskiy, J. K. Parker, M. Faka, and L. Methven. 2017. Whey protein mouth drying influenced by thermal denaturation. Food Qual. Prefer. 56:233-240. https://doi .org/10.1016/j.foodqual.2016.03.008.

Cannan, R. K., A. H. Palmer, and A. C. Kibrick. 1942. The hydrogen ion dissociation curve of beta-lactoglobulin. J. Biol. Chem. 142:803-822.

Carter, B. G., and M. A. Drake. 2018. Invited review: The effects of processing parameters on the flavor of whey protein ingredients. J. Dairy Sci. 101:6691-6702. https://doi.org/10.3168/jds.2018-14571.

Carunchia Whetstine, M. E., A. E. Croissant, and M. A. Drake. 2005. Characterization of dried whey protein concentrate and isolate flavor. J. Dairy Sci. 88:3826-3839. https://doi.org/10.3168/jds.S0022 $-0302(05) 73068-\mathrm{X}$.

Carunchia Whetstine, M. E., J. D. Parker, M. A. Drake, and D. K. Larick. 2003. Determining flavor and flavor variability in commercially produced liquid Cheddar whey. J. Dairy Sci. 86:439-448. https://doi.org/10.3168/jds.S0022-0302(03)73622-4.

Çelebioğlu, H. Y., S. Lee, and I. S. Chronakis. 2020. Interactions of salivary mucins and saliva with food proteins: A review. Crit. Rev. Food Sci. Nutr. 60:64-83.

Chandrashekar, J., M. A. Hoon, N. J. P. Ryba, and C. S. Zuker. 2006. The receptors and cells for mammalian taste. Nature 444:288-294. https://doi.org/10.1038/nature05401.

Childs, J. L., and M. A. Drake. 2010. Consumer perception of astringency in clear acidic whey protein beverages. J. Food Sci. 75:S513S521. https://doi.org/10.1111/j.1750-3841.2010.01834.x.

Colonna, A. E., D. O. Adams, and A. Noble. 2004. Comparison of procedures for reducing astringency carry-over effects in evaluation of 
red wines. Aust. J. Grape Wine Res. 10:26-31. https://doi.org/10 .1111/j.1755-0238.2004.tb00005.x.

Damak, S., M. Rong, K. Yasumatsu, Z. Kokrashvili, and V. Varadarajan. 2003. Detection of sweet and umami taste in the absence of taste receptor T1r3. Science 301:850-853. https://doi.org/10 .1126 /science. 1087155 .

Dawes, C., A. M. O'Connor, and J. M. Aspen. 2000. The effect on human salivary flow rate of the temperature of a gustatory stimulus. Arch. Oral Biol. 45:957-961. https://doi.org/10.1016/S0003 -9969(00)00070-4.

de Vicente, J., J. R. Stokes, and H. A. Spikes. 2006. Soft lubrication of model hydrocolloids. Food Hydrocoll. 20:483-491. https://doi.org/ 10.1016/j.foodhyd.2005.04.005.

des Gachons, C. P., E. Mura, C. Speziale, C. J. Favreau, G. F. Dubreuil, and P. A. S. Breslin. 2012. Opponency of astringent and fat sensations. Curr. Biol. 22:R829-R830. https://doi.org/10.1016/j .cub.2012.08.017.

DeSimone, J. A., and V. Lyall. 2006. Taste receptors in the gastrointestinal tract III. Salty and sour taste: Sensing of sodium and protons by the tongue. Am. J. Physiol. Gastrointest. Liver Physiol. 291:G1005-G1010. https://doi.org/10.1152/ajpgi.00235.2006.

Douglas, W. H., E. S. Reeh, N. Ramasubbu, P. A. Raj, K. K. Bhandary, and M. J. Levine. 1991. Statherin: A major boundary lubricant of human saliva. Biochem. Biophys. Res. Commun. 180:9197. https://doi.org/10.1016/S0006-291X(05)81259-8.

Drake, M. A. 2006. Flavor and flavor carry-through of whey proteins in beverages. Pages 292-300 in The Wonders of Whey ... Catch the Power; Proc. 4th Int. Whey Conf. American Dairy Products Institute, Elmhurst, IL.

Drake, M. A. 2007. Invited review: Sensory analysis of dairy foods. J. Dairy Sci. 90:4925-4937. https://doi.org/10.3168/jds.2007-0332.

Evans, J., J. Zulewska, M. Newbold, M. A. Drake, and D. M. Barbano. 2010. Comparison of composition and sensory properties of $80 \%$ whey protein and milk serum protein concentrates. J. Dairy Sci. 93:1824-1843. https://doi.org/10.3168/jds.2009-2723.

Farías, M., M. Martinez, and A. Pilosof. 2010. Casein glycomacropeptide $\mathrm{pH}$-dependent self-assembly and cold gelation. Int. Dairy J. 20:79-88. https://doi.org/10.1016/j.idairyj.2009.09.002.

Gibbins, H. L., and G. H. Carpenter. 2013. Alternative mechanisms of astringency - What is the role of saliva? J. Texture Stud. 44:364375. https://doi.org/10.1111/jtxs.12022.

Gibbins, H. L., G. E. Yakubov, G. B. Proctor, S. Wilson, and G. H. Carpenter. 2014. What interactions drive the salivary mucosal pellicle formation? Colloids Surf. B Biointerfaces 120:184-192. https: //doi.org/10.1016/j.colsurfb.2014.05.020.

Hans, R., S. Thomas, B. Garla, R. J. Dagli, and M. K. Hans. 2016. Effect of various sugary beverages on salivary $\mathrm{pH}$, flow rate, and oral clearance rate amongst adults. Scientifica (Cairo) 2016:5027283.

Hartwig, P., and M. R. McDaniel. 1995. Flavor characteristics of lactic, malic, citric and acetic acids at various $\mathrm{pH}$ levels. J. Food Sci. 60:384-388. https://doi.org/10.1111/j.1365-2621.1995.tb05678.x.

Harwood, W. S., and M. A. Drake. 2019. Understanding implicit and explicit consumer desires for protein bars, powders, and beverages. J. Sens. Stud. 34:e12493. https://doi.org/10.1111/joss.12493.

Hay, D. I., and F. G. Oppenheim. 1974. The isolation from human parotid saliva of a further group of proline-rich proteins. Arch. Oral Biol. 19:627-632, IN9. https://doi.org/10.1016/0003 -9969(74) 90130-7.

Horne, J., J. Hayes, and H. T. Lawless. 2002. Turbidity as a measure of salivary protein reactions with astringent substances. Chem. Senses 27:653-659. https://doi.org/10.1093/chemse/27.7.653.

Hsein, H., G. Garrait, E. Beyssac, and V. Hoffart. 2015. Whey protein mucoadhesive properties for oral drug delivery: Mucin-whey protein interaction and mucoadhesive bond strength. Colloid Surf. B Biointerfaces 136:799-808. https://doi.org/10.1016/j.colsurfb.2015 .10 .016 .

Iorgulescu, G. 2009. Saliva between normal and pathological. Important factors in determining systemic and oral health. J. Med. Life 2:303-307.

Kelly, M., B. Vardhanabhuti, P. Luck, M. A. Drake, J. Osborne, and E. A. Foegeding. 2010. Role of protein concentration and pro- tein-saliva interactions in the astringency of whey proteins at low pH. J. Dairy Sci. 93:1900-1909. https://doi.org/10.3168/jds.2009 $-2853$.

LaClair, C. E., and M. R. Etzel. 2009. Turbidity and protein aggregation in whey protein beverages. J. Food Sci. 74:C526-C535. https: //doi.org/10.1111/j.1750-3841.2009.01260.x.

Laguna, L., and A. Sarkar. 2017. Oral tribology: Update on the relevance to study astringency in wines. Tribol. Mater. Surf. Interfaces 11:116-123. https://doi.org/10.1080/17515831.2017.1347736.

Lawless, H., and H. Heymann. 2010. Descriptive analysis. Pages 227257 in Sensory Evaluation of Food. Springer-Verlag, New York, NY.

Lawless, H. T., J. Horne, and P. Giasi. 1996. Astringency of organic acids is related to $\mathrm{pH}$. Chem. Senses 21:397-403. https://doi.org/ 10.1093/chemse/21.4.397.

Lee, A. P., D. M. Barbano, and M. A. Drake. 2017. The influence of ultra-pasteurization by indirect heating versus direct steam injection on skim and $2 \%$ fat milks. J. Dairy Sci. 100:1688-1701. https: //doi.org/10.3168/jds.2016-11899.

Lee, C. A., and Z. M. Vickers. 2008. The astringency of whey protein beverages is caused by their acidity. Int. Dairy J. 18:1153-1156. https://doi.org/10.1016/j.idairyj.2008.06.010.

Lee, C. A., and Z. M. Vickers. 2010. Discrimination among astringent samples is affected by choice of palate cleanser. Food Qual. Prefer. 21:93-99. https://doi.org/10.1016/j.foodqual.2009.08.003.

Lesschaeve, I., and A. C. Noble. 2005. Polyphenols: Factors influencing their sensory properties and their effects on food and beverage preferences. Am. J. Clin. Nutr. 81:330S-335S. https://doi.org/10 $.1093 /$ ajcn/81.1.330S.

Li, Y., H. S. Joyner, B. G. Carter, and M. A. Drake. 2018a. Effects of fat content, pasteurization method, homogenization pressure, and storage time on the mechanical and sensory properties of bovine milk. J. Dairy Sci. 101:2941-2955. https://doi.org/10.3168/ jds.2017-13568.

Li, Y., H. S. Joyner (Melito), A. P. Lee, and M. A. Drake. 2018b. Impact of pasteurization method and fat on milk: Relationships among rheological, tribological, and astringency behaviors. Int. Dairy J. 78:28-35. https://doi.org/10.1016/j.idairyj.2017.10.006.

Liao, Y., Z. Peng, L. Chen, Y. Zhang, Q. Cheng, A. K. Nussler, W. Bao, L. Liu, and W. Yang. 2019. Prospective views for whey protein and/or resistance training against age-related sarcopenia. Aging Dis. 10:157-173. https://doi.org/10.14336/AD.2018.0325.

Ma, S., H. Lee, Y. Liang, and F. Zhou. 2016. Astringent mouthfeel as a consequence of lubrication failure. Angew. Chem. Int. Ed. Engl. 55:5793-5797.

Mahajan, S. S., L. Goddik, and M. C. Qian. 2004. Aroma compounds in sweet whey powder. J. Dairy Sci. 87:4057-4063. https://doi .org/10.3168/jds.S0022-0302(04)73547-X.

Nielsen Company. 2015. We are what we eat: Healthy eating trends around the world. The Nielsen Company, New York, NY.

Oltman, A. E., K. Lopetcharat, E. Bastian, and M. A. Drake. 2015. Identifying key attributes for protein beverages. J. Food Sci. 80:S1383-S1390. https://doi.org/10.1111/1750-3841.12877.

Paddon-Jones, D., and B. B. Rasmussen. 2009. Dietary protein recommendations and the prevention of sarcopenia. Curr. Opin. Clin. Nutr. Metab. Care 12:86-90. https://doi.org/10.1097/MCO .0b013e32831cef8b.

Peleg, H., K. K. Bodine, and A. C. Noble. 1998. The influence of acid on astringency of alum and phenolic compounds. Chem. Senses 23:371-378. https://doi.org/10.1093/chemse/23.3.371.

Pelegrine, D. H. G., and C. A. Gasparetto. 2005. Whey proteins solubility as function of temperature and pH. LTW Food Sci. Technol. 40:1304-1307.

Pennings, B., Y. Boirie, J. Senden, A. Gijsen, H. Kuipers, and L. van Loon. 2011. Whey protein stimulates postprandial muscle protein accretion more effectively than do casein and casein hydrolysate in older men. Am. J. Clin. Nutr. 93:997-1005. https://doi.org/10 .3945 /ajcn.110.008102

Ployon, S., M. Morzel, C. Belloir, A. Bonnotte, E. Bourillot, L. Briand, E. Lesniewska, J. Lherminier, E. Aybeke, and F. Canon. 2018. Mechanisms of astringency: Structural alteration of the oral mu- 
cosal pellicle by dietary tannins and protective effect of bPRPs. Food Chem. 253:79-87. https://doi.org/10.1016/j.foodchem.2018 .01 .141 .

Ross, C. F., C. H. Hinken, and K. Weller. 2007. Efficacy of palate cleansers for reduction of astringency carryover during repeated ingestions of red wine. J. Sens. Stud. 22:293-312. https://doi.org/ 10.1111/j.1745-459X.2007.00107.x.

Rossetti, D., J. H. H. Bongaerts, E. Wantling, J. R. Stokes, and A. M. Williamson. 2009. Astringency of tea catechins: More than an oral lubrication tactile percept. Food Hydrocoll. 23:1984-1992.

Rossetti, D., G. E. Yakubov, J. R. Stokes, A. M. Williamson, and G. G. Fuller. 2008. Interaction of human whole saliva and astringent dietary compounds investigated by interfacial shear rheology. Food Hydrocoll. 22:1068-1078. https://doi.org/10.1016/j.foodhyd 2007.05.014.

Rubico, S. M., and M. R. McDaniel. 1992. Sensory evaluation of acids by free-choice profiling. Chem. Senses 17:273-289. https://doi.org/ 10.1093/chemse/17.3.273.

Sano, H., T. Egashira, Y. Kinekawa, and N. Kitabatake. 2005. Astringency of bovine milk whey protein. J. Dairy Sci. 88:2312-2317. https://doi.org/10.3168/jds.S0022-0302(05)72909-X.

Sarkar, A., E. Andablo-Reyes, M. Bryant, D. Dowson, and A. Neville. 2019. Lubrication of soft oral surfaces. Curr. Opin. Colloid Interface Sci. 39:61-75. https://doi.org/10.1016/j.cocis.2019.01.008.

Shaikh, R., T. R. R. Singh, M. J. Garland, A. D. Woolfson, and R. F. Donnelly. 2011. Mucoadhesive drug delivery systems. J. Pharm. Bioallied Sci. 3:89-100.

Slomiany, B. L., V. L. N. Murty, J. Piotrowski, and A. Slomiany. 1996. Salivary mucins in oral mucosal defense. Gen. Pharmacol. 27:761-771. https://doi.org/10.1016/0306-3623(95)02050-0.

Smith, A. K., H. June, and A. C. Noble. 1996. Effects of viscosity on the bitterness and astringency of grape seed tannin. Food Qual. Prefer. 7:161-166. https://doi.org/10.1016/S0950-3293(96)00028 -6 .

Smith, A. K., and A. C. Noble. 1998. Effects of increased viscosity on the sourness and astringency of aluminum sulfate and citric acid. Food Qual. Prefer. 9:139-144. https://doi.org/10.1016/S0950 $-3293(97) 00047-5$.

Soares, S., N. Mateus, and V. de Freitas. 2012. Carbohydrates inhibit salivary proteins precipitation by condensed tannins. J. Agric. Food Chem. 60:3966-3972. https://doi.org/10.1021/jf3002747.

Sowalsky, R. A., and A. C. Noble. 1998. Comparison of the effects of concentration, $\mathrm{pH}$ and anion species on astringency and sourness of organic acids. Chem. Senses 23:343-349.

Tabak, L. A., M. J. Levine, I. D. Mandel, and S. A. Ellison. 1982. Role of salivary mucins in the protection of the oral cavity. J. Oral Pathol. 11:1-17. https://doi.org/10.1111/j.1600-0714.1982 .tb00138.x.

Taira, S., M. Ono, and N. Matsumoto. 1997. Reduction of persimmon astringency by complex formation between pectin and tannins. Postharvest Biol. Technol. 12:265-271. https://doi.org/10.1016/ S0925-5214(97)00064-1.

Tang, J. E., D. R. Moore, G. Kujbida, M. Tarnopolsky, and S. Phillips. 2009. Ingestion of whey hydrolysate, casein, or soy protein isolate: Effects on mixed muscle protein synthesis at rest and following resistance exercise in young men. J. Appl. Physiol. 107:987-992. https://doi.org/10.1152/japplphysiol.00076.2009.

Torrico, D. D., W. Jirangrat, J. Wang, P. Chompreeda, S. Sriwattana, and W. Prinyawiwatkul. 2018. Novel modelling approaches to characterize and quantify carryover effects on sensory acceptability. Foods 7:186. https://doi.org/10.3390/foods7110186.

Upadhyay, R., N. Brossard, and J. Chen. 2016. Mechanisms underlying astringency: Introduction to an oral tribology approach. J.
Phys. D Appl. Phys. 49:104003. https://doi.org/10.1088/0022 $-3727 / 49 / 10 / 104003$

Vardhanabhuti, B., P. W. Cox, I. T. Norton, and E. A. Foegeding. 2011. Lubricating properties of human whole saliva as affected by B-lactoglobulin. Food Hydrocoll. 25:1499-1506. https://doi.org/10 .1016/j.foodhyd.2011.02.021.

Vardhanabhuti, B., M. A. Kelly, P. J. Luck, M. A. Drake, and E. A. Foegeding. 2010. Roles of charge interactions on astringency of whey proteins at low pH. J. Dairy Sci. 93:1890-1899. https://doi .org/10.3168/jds.2009-2780.

Vickers, Z. A., E. E. Morris, and M. Savaria. 2008. Effectiveness of palate cleansers for evaluating sourness. J. Sens. Stud. 23:526-532. https://doi.org/10.1111/j.1745-459X.2008.00170.x.

Wagoner, T. B., and E. A. Foegeding. 2017. Whey protein-pectin soluble complexes for beverage applications. Food Hydrocoll. 63:130138. https://doi.org/10.1016/j.foodhyd.2016.08.027.

Wagoner, T., B. Vardhanabhuti, and E. A. Foegeding. 2016. Designing whey protein-polysaccharide particles for colloidal stability. Annu. Rev. Food Sci. Technol. 7:93-116. https://doi.org/10.1146/ annurev-food-041715-033315.

Withers, C. A., M. J. Lewis, M. A. Gosney, and L. Methven. 2014. Potentials sources of mouth drying in beverages fortified with dairy proteins: A comparison of casein- and whey-rich ingredients. J. Dairy Sci. 97:1233-1247. https://doi.org/10.3168/jds.2013-7273.

Wright, B. J., S. E. Zevchak, J. M. Wright, and M. A. Drake. 2009. The impact of agglomeration and storage on flavor and flavor stability of whey protein concentrate $80 \%$ and whey protein isolate. J. Food Sci. 74:S17-S29. https://doi.org/10.1111/j.1750-3841.2008 .00975.x.

Wright, J. W., M. E. Carunchia-Whetstine, R. E. Miracle, and M. A. Drake. 2006. Characterization of cabbage off-flavor in whey protein isolate. J. Food Sci. 71:C86-C90. https://doi.org/10.1111/ j.1365-2621.2006.tb08887.x.

Ye, A., C. Streicher, and H. Singh. 2011. Interactions between whey proteins and salivary proteins as related to astringency of whey protein beverages at low pH. J. Dairy Sci. 94:5842-5850. https:// doi.org/10.3168/jds.2011-4566.

Ye, A., T. Zheng, J. Z. Ye, and J. Singh. 2012. Potential role of the binding of whey proteins to human buccal cells on the perception of astringency in whey protein beverages. Physiol. Behav. 106:645650. https://doi.org/10.1016/j.physbeh.2012.04.026.

Zhang, M., Y. Jo, K. Lopetcharat, and M. A. Drake. 2020. Comparison of a central location test versus a home usage test for consumer perception of ready-to-mix protein beverages. J. Dairy Sci 103:3107-3124. https://doi.org/10.3168/jds.2019-17260.

Zhang, Y., M. A. Hoon, J. Chandrashekar, K. L. Mueller, B. Cook, D. Wu, C. S. Zuker, and N. J. P. Ryba. 2003. Coding of sweet, bitter, and umami tastes: Different receptor cells sharing similar signaling pathways. Cell 112:293-301. https://doi.org/10.1016/S0092 -8674(03)00071-0.

Zhao, G. Q., Y. Zhang, M. A. Hoon, J. Chandrashekar, I. Erlenbach, N. J. P. Ryba, and C. S. Zuker. 2003. The receptors for mammalian sweet and umami taste. Cell 115:255-266. https://doi.org/10 .1016/S0092-8674(03)00844-4.

Zittle, C. A. 1956. Solubility transformation of alpha-lactalbumin. Arch. Biochem. Biophys. 64:144-151. https://doi.org/10.1016/ 0003-9861(56)90250-8.

\section{ORCIDS}

M. A. Drake $®$ https://orcid.org/0000-0002-4744-2493 